\title{
Synthesis and In vitro Antimalarial Activity of Alkyl Esters of Gallate as a Growth Inhibitor of Plasmodium falciparum
}

\author{
ADE ARSIANTII ${ }^{1,3, *}$, HENDRI ASTUTY ${ }^{2}$, FADILAH ${ }^{1,3}$, DANIEL MARTIN SIMADIBRATA ${ }^{5}$, \\ ZOYA MARIE ADYASA ${ }^{5}$, DANIEL AMARTYA ${ }^{5}$, ANTON BAHTIAR ${ }^{4}$, \\ HIROKI TANIMOTO ${ }^{6}$ and KIYOMI KAKIUCHI ${ }^{6}$
}

${ }^{1,4}$ Department of Medical Chemistry Faculty of Medicine, University of Indonesia, Indonesia. ${ }^{2}$ Department of Parasitology, Faculty of Medicine, University of Indonesia, Indonesia.

${ }^{3}$ Drug Development Research Cluster, Indonesia Medical Education and Research Institute (IMERI), Faculty of Medicine, University of Indonesia, Indonesia.

${ }^{5}$ Department of Pharmacology, Faculty of Pharmacy, University Indonesia, Depok, Indonesia. ${ }^{6}$ Graduate School of Materials Science, Nara Institute of Science and Technology, Nara, Japan.

*Corresponding author E-mail: arsi_ade2002@yahoo.com

http://dx.doi.org/10.13005/ojc/340207

(Received: January 09, 2018; Accepted: February 01, 2018)

\section{ABSTRACT}

This study is aimed to synthesize alkyl esters gallate and determine its in vitro antimalarial activity against parasite Plasmodium falciparum. Fourteen compounds of alkyl esters gallate were synthesized by esterification of the carboxyl group of gallic acid with a series of alkyl alcohols, as well as methoxylation of the hydroxy groups on the aromatic ring of gallic acid. Antimalarial activity of the synthesized alkyl esters gallate were expressed by $I C_{50}$ value, with gallic acid as an original compound and artemisin as a positive control. Compared to gallic acid, eleven synthesized compounds of alkyl esters gallate, have a greater antimalarial activity against Plasmodium falciparum. On the other hand, three compounds, that are propyl gallate, butyl gallate and trimethoxy methyl gallate, showed a lower antimalarial activity. Moreover, compared to gallic acid $\left(\mathrm{IC}_{50}: 194.86 \mathrm{mM}\right)$ and artemisin $\left(\mathrm{IC}_{50}: 0.5 \mathrm{mM}\right)$, two synthesized compounds of alkyl gallates, namely methyl gallate and hexyl gallate exhibited the stronger antimalarial activity against Plasmodium falciparum, with $\mathrm{IC}_{50}$ value of $0.03 \mathrm{mM}$ and $0.11 \mathrm{mM}$, respectively. Our result clearly demonstrated that methyl gallate and hexyl gallate as a promising candidate for the new antimalarial agents.

Keywords: Synthesis, Alkyl ester gallate, In vitro, Antimalarial, Plasmodium falciparum.

\section{INTRODUCTION}

Malaria is one of the plasmodium parasite infection which found in many tropical and subtropical countries. According to data from the WHO in 2010, around 2.3 to 3.3 billion people were at risk of malaria, especially in Africa and some countries in Asia, Latin America, Middle East and some parts of Europe. ${ }^{1}$ In the African region of $81 \%$ of cases of malaria, $91 \%$ of which is mortality, particularly in children under age 5 and pregnant women who had the most severe infection. ${ }^{2,3}$ In

This is an 2 Open Access article licensed under a Creative Commons Attribution-NonCommercial-ShareAlike 4.0 International License (https://creativecommons.org/licenses/by-nc-sa/4.0/ ), which permits unrestricted NonCommercial use, distribution and reproduction in any medium, provided the original work is properly cited. 
Indonesia, there are 396 malaria endemic district in 2007 , and approximately $45 \%$ of the population live in areas at risk of malaria. ${ }^{3}$ Province of Papua, West Papua, East Nusa Tenggara are the provinces with the highest Annual parasite incidence API that is equal to $18.03 ; 17.86$; and 12.14 per 1000 population. ${ }^{4}$ Strategic Plan of the Ministry of Health Republic of Indonesia from 2010 to 2014 targeted malaria control can reduce morbidity from 2 to 1 per 1,000 population. ${ }^{5}$ There are four species of the genus Plasmodium that can cause infections in humans. Plasmodium falciparum causes malaria tropical or malaria falciparum, Plasmodium vivax causes tertian malaria, Plasmodium malariae causes malaria kuartana, and Plasmodium ovale causes malaria ovale. Among four types of malaria infection, malaria falciparum is the most dangerous type of malaria, because it can cause serious complications and death rate is highest among all types of malaria. ${ }^{6}$

Currently, the treatment of malaria due to Plasmodium falciparum parasite relies on the use of chloroquine or synergistic combination of aminokuinolon-antifolate and sulfadoxine pyrimethamine. However, a recent study reported that antimalarial drugs have shown resistance, so it is no longer effective in use. The emergence of resistancy of antimalarial drugs against malaria vectors, underlying the need for new drugs that are more potent, more effective and safer. ${ }^{7}$
Previous researchers reported that the gallic acid (1) and some of the gallic acid ester compounds showing antimalarial activity. and co-workers reported that the combination of alkyl gallate, i.e. propyl gallate with atovaquone, has antimalarial activity more powerful than the combination of atovaquone with gallic acid. ${ }^{10}$ The results of this study revealed that alkyl ester derivative of gallic acid has the potential to be developed as an antimalarial agent. This fact led us to carry out research that is aimed to synthesize gallic acid derivatives of alkyl ester gallate, compound 2-15 (Fig. 1), and evaluate its in vitro antimalarial activity as a growth inhibitor of Plasmodium falciparum.

Recently, we have accomplished in silico docking study of gallic acid derivatives as inhibitor of malarial dihydrofolate. ${ }^{11}$ Our previous studies also showed that the methylation of hydroxyl group on the aromatic ring of gallic acid will enhance the biological activity, therefore in this study, we modify the hydroxyl groups on the aromatic ring of butyl gallate become rmonomethoxy butyl gallate in derivatives 13 , dimethoxy butyl gallate in derivatives 14 and trimethoxy butyl gallate in derivative 15 (Fig. 1). Modification of hydroxyl group into methoxy group is expected to increase antimalarial activity of derivatives 13,14 and 15 .

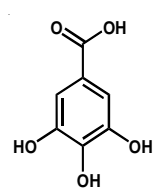

Gallic acid (1)

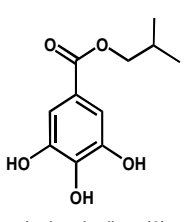

Isobutylgallate (6)
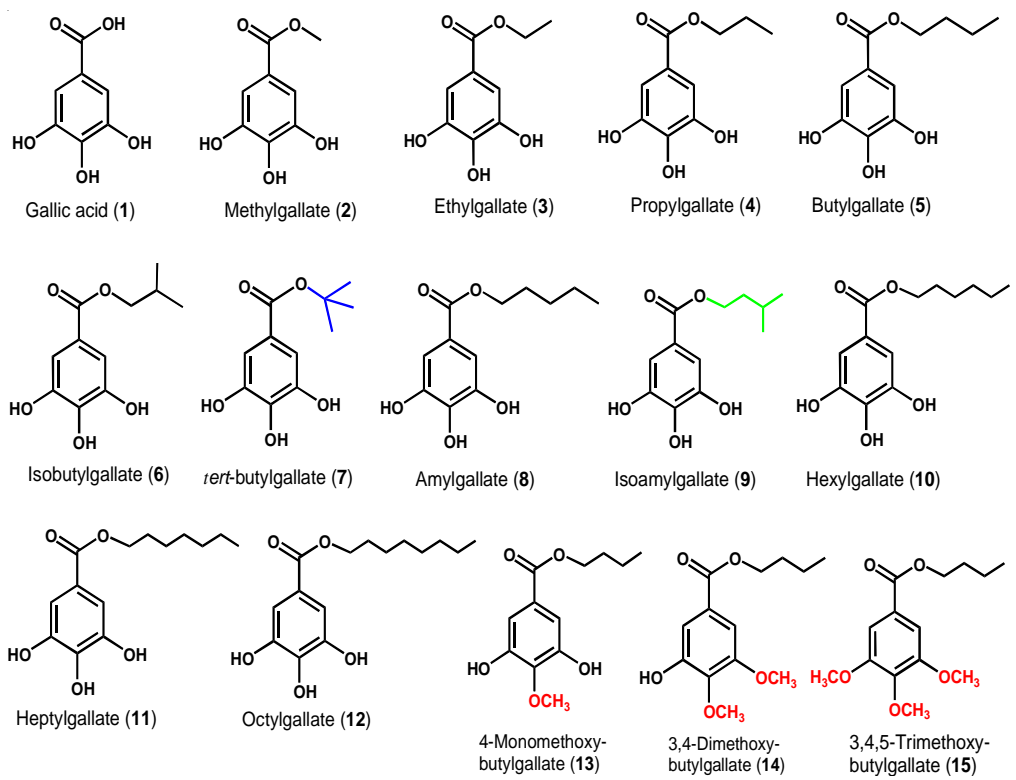

Fig. 1. Structure of gallic acid (1), and its desired alkyl ester derivatives 2-15 


\section{EXPERIMENTAL}

\section{Design structure of alkyl esters gallate}

Twelve alkyl ester derivatives of gallic acid compound 2-12 (Fig. 1) were designed by esterification of carboxyl group in gallic acid with a series of alkyl alcohol, in which four derivatives, namely compound $2,3,4,5,8,10,11$ and 12 , were designed to have a linear aliphatic carbon chain in alkyl ester group, whereas compound 6, 7 and 9 were designed to have a branched alphatic carbon chain. Derivatives 13,14 and 15 were designed by methylation of hydroxyl group in gallic acid followed by hydrolysis of metyl ester and esterification of carboxyl group with butyl alcohol.

\section{General experimental method}

All Chemical reactions were performed in an oven-dried glassware. Chloroform and methanol in technical grade were purchased from Brataco Indonesia chemical distributor, and were distilled prior to use. Alkyl alcohol and THF were obtained from Wako Pure Chemical Industries. Gallic acid, EDCI and DMAP were purchased from Sigma-Aldrich Chemical Company. Flash column chromatography was carried out using Merck \& Co. silica gel 60. Reaction and fractions of chromatography were analyzed by Merck \& Co. precoated silica gel $60 \mathrm{~F}_{254}$ plates. Compounds were visualized by an ultraviolet lamp (254 nm) and by staining with ninhydrin (in EtOH). ${ }^{1} \mathrm{H}$ NMR and ${ }^{13} \mathrm{C}$ NMR spectra were recorded on JEOL JNM-ECP500 (500 MHz) spectrometert with tetramethylsilane $(\delta 0)$ and acetone $(\delta 2.05)$ as an internal standard. Mass spectra were measured by JEOL JMS-AX 700 spectrometer. Synthesis and in vitro antimalarial activity evaluation" alkyl esters gallate were conducted in Department of Medical Chemistry, Department of Parasitology, Faculty of Medicine, University of Indonesia. Structure elucidation of the synthesized alkyl esters gallate were carried out in Graduate School of Materials Science, Nara Institute of Science and Technology (NAIST), Japan.

General procedure of esterification of gallic acid

To the solution containing gallic acid (250 mg, $1.47 \mathrm{mmol}$ ) in THF solvent at $0^{\circ} \mathrm{C}$ is added alcohol $(2.94 \mathrm{mmol})$ and the DIC $(0.34 \mathrm{~mL}$, $2.205 \mathrm{mmol}$ ) as an activator. The reaction mixture was stirred for $1 \mathrm{~h}$ at $0^{\circ} \mathrm{C}$, then added DMAP catalyst (18 $\mathrm{mg}, 0.147 \mathrm{mmol}$ ), and stirred again for the next $6 \mathrm{~h}$ at $0^{\circ} \mathrm{C}$, then allowed to reach room temperature. The reaction was terminated when the TLC analysis showed no spot of the remaining gallic acid. After the reaction is complete, the reaction mixture is diluted with ether, filtered, evaporated, and purified by column silica gel chromatography. Pure compounds were analyzed by Thin Layer Chromatography (TLC), Nuclear Magnetic Resonance Spectrometer (NMR), and High Resolution Mass Spectrometer (HRMS).

\section{General procedure of methylation of gallic acid}

To the gallic acid solution in DMF at $0^{\circ} \mathrm{C}$, $\mathrm{K}_{2} \mathrm{CO}_{3}$ and $\mathrm{Mel}$ were added. The reaction mixture is stirred at $0^{\circ} \mathrm{C}$ and allowed to reach at room temperature overnight, with a total reaction time of 18-24 hours. The reaction mixture is then diluted by addition of ethylacetate, and washed repeatedly with saturated $\mathrm{NaHCO}_{3}$ solution. The ethylacetate phase is then washed further with a saturated $\mathrm{NaCl}$ (Brine) solution to withdraw residual water, then dried with anhydrous $\mathrm{MgSO}_{4}$, filtered, and concentrated, resulting in a crude extract of methylated product. Furthermore, the crude extract is purified by silica gel chromatography column. Pure compounds were analyzed by Thin Layer Chromatography (TLC), Nuclear Magnetic Resonance Spectrometer, and High Resolution Mass Spectrometer.

\section{General procedure of hydrolysis of methylated product}

A solution of methylated product and $\mathrm{LiOH}$ monohydrate $0.5 \mathrm{M}$ in mixture THF:Methanol (3:1) were stirred at room temperature for 24 hours. The reaction mixture was then acidified using $\mathrm{KHSO}_{4}$ $1 \mathrm{M}$ until $\mathrm{pH}=3$, subsequently, $15 \mathrm{~mL}$ of aquadest was added, and extracted with $3 \times 15 \mathrm{~mL}$ ethyl acetate. This phase was washed with saturated $\mathrm{NaCl}$ and dried over anhydrous $\mathrm{MgSO}_{4}$. The filtrate was concentrated, resulting in a crude extract containing a mixture of 4-monomethoxy-gallic acid, 3,4dimethoxygallic acid, 3,4,5-trimethoxygallic acid. Furthermore, the mixture is purified by silica gel chromatography column. Pure compounds were analyzed by Thin Layer Chromatography, Nuclear Magnetic Resonance Spectrometer, and High Resolution Mass Spectrometer. 
Experimental data of TLC, NMR and HRMS of the synthesized alkyl ester gallate methylgallate (2)

Methylgallate ( $194.5 \mathrm{mg}, 72 \%$ yield) was obtained from flash column chromatography on silica gel of the crude extract (gradient elution 100:1 to $\left.95: 1 \mathrm{CHCl}_{3} / \mathrm{CH}_{3} \mathrm{OH}\right)$ as a pale yellow solid. $R_{f}$ $0.36\left(3: 1 \mathrm{CHCl}_{3} / \mathrm{CH}_{3} \mathrm{OH}\right) ;{ }^{1} \mathrm{H}$ NMR $(500 \mathrm{MHz}$, acetone- $\left.d_{6}\right)$ : : ${ }^{1} \mathrm{HNMR}: 7.10(2 \mathrm{H}, \mathrm{s})$; $3.85(3 \mathrm{H}, \mathrm{s})$. ${ }^{13} \mathrm{C}$ NMR $\left(125 \mathrm{MHz}\right.$, acetone- $\left.d_{6}\right): 167.400 ; 150.080$ (2C); 140.168; 126.690; 109.874 (2C); 60.504. HRMS El+ calcd for $\mathrm{C}_{8} \mathrm{H}_{8} \mathrm{O}_{5}[\mathrm{M}]^{+}: 184.0372$, found: 184.0355 .

\section{Ethylgallate (3)}

Ethyl gallate $(201.0 \mathrm{mg}, 69 \%$ yield) was obtained from flash column chromatography on silica gel of the crude extract (gradient elution 100:1 to $\left.90: 1 \mathrm{CHCl}_{3} / \mathrm{CH}_{3} \mathrm{OH}\right)$ as a light brown solid. $R_{f}$ $0.42\left(3: 1 \mathrm{CHCl}_{3} / \mathrm{CH}_{3} \mathrm{OH}\right) ;{ }^{1} \mathrm{H} \mathrm{NMR}(500 \mathrm{MHz}$, acetone- $\left.d_{6}\right): 7.10(2 \mathrm{H}, \mathrm{s}) ; 4.23(2 \mathrm{H}, \mathrm{q}, \mathrm{J}=6.9 \mathrm{~Hz})$; $1.29(3 \mathrm{H}, \mathrm{t}, \mathrm{J}=7.4 \mathrm{~Hz}) ;{ }^{13} \mathrm{C} \mathrm{NMR}\left(125 \mathrm{MHz}\right.$, acetone- $\left.d_{6}\right)$ : 166.666; 145.939 (2C); 138.547; 121.978; 109.645 (2C); 60.847; 14.567. HRMS El ${ }^{+}$calcd for $\mathrm{C}_{9} \mathrm{H}_{10} \mathrm{O}_{5}$ [M]+: 198.0528, found:198.0528.

\section{Propylgallate (4)}

Propylgallate $(205.5 \mathrm{mg}, 66 \%$ yield) was obtained from flash column chromatography on silica gel of the crude extract (gradient elution 50:1 to $5: 1 \mathrm{CHCl}_{3} / \mathrm{CH}_{3} \mathrm{OH}$ ) as a pale brown solid. $R_{f} 0.46$ (4:1 $\left.\mathrm{CHCl}_{3} / \mathrm{CH}_{3} \mathrm{OH}\right) ;{ }^{1} \mathrm{H}$ NMR (500 MHz, acetone- $d_{6}$ ): $7.10(2 \mathrm{H}, \mathrm{s}) ; 4.14(2 \mathrm{H}, \mathrm{t}, \mathrm{J}=7.4 \mathrm{~Hz}) ; 1.75-1.67(2 \mathrm{H}, \mathrm{m})$; $0.97(3 \mathrm{H}, \mathrm{t}, \mathrm{J}=8.0 \mathrm{~Hz}) ;{ }^{13} \mathrm{C} \mathrm{NMR}\left(125 \mathrm{MHz}\right.$, acetone- $\left.d_{6}\right)$ : 166.723; 145.967 (2C); 138.585; 121.931; 109.626 (2C); 66.389; 22.742; 10.704. HRMS El ${ }^{+}$Calcd for $\mathrm{C}_{10} \mathrm{H}_{12} \mathrm{O}_{5}[\mathrm{M}]^{+}:$212.0685, found: 212.0663 .

\section{Butylgallate (5)}

Butylgallate $(245.6 \mathrm{mg}, 74 \%$ yield) was obtained from flash column chromatography on silica gel of the crude extract (gradient elution 20:1 to $1: 1 \mathrm{CHCl}_{3} / \mathrm{CH}_{3} \mathrm{OH}$ ) as a dark brown solid. $R_{f} 0.50$ (4:1 $\left.\mathrm{CHCl}_{3} / \mathrm{CH}_{3} \mathrm{OH}\right) ;{ }^{1} \mathrm{H}$ NMR $\left(500 \mathrm{MHz}\right.$, acetone- $\left.d_{6}\right)$ : $7.10(2 \mathrm{H}, \mathrm{s}) ; 4.19(2 \mathrm{H}, \mathrm{t}, \mathrm{J}=8.0 \mathrm{~Hz}) ; 1.72-1.64(2 \mathrm{H}, \mathrm{m})$; $1.49-1.40(2 \mathrm{H}, \mathrm{m}) ; 0.94(3 \mathrm{H}, \mathrm{t}, \mathrm{J}=8.6 \mathrm{~Hz}) ;{ }^{13} \mathrm{C}$ NMR $\left(125 \mathrm{MHz}\right.$, acetone- $\left.d_{6}\right)$ : $166.685 ; 145.948(2 \mathrm{C})$; 138.547; 121.988; 109.664; 109.626; 64.644; 31.526; 19.890; 13.985. HRMS El ${ }^{+}$calcd for $\mathrm{C}_{11} \mathrm{H}_{14} \mathrm{O}_{5}[\mathrm{M}]^{+}$: 226.0843, found: 226.0843 .

\section{Isobutylgallate (6)}

Isobutylgallate (190.6 mg, 57\% yield) was obtained from flash column chromatography on silica gel of the crude extract (gradient elution 20:1 to $\left.1: 1 \mathrm{CHCl}_{3} / \mathrm{CH}_{3} \mathrm{OH}\right)$ as a brown solid. $R_{f} 0.55(4: 1$ $\left.\mathrm{CHCl}_{3} / \mathrm{CH}_{3} \mathrm{OH}\right) ;{ }^{1} \mathrm{H} \mathrm{NMR}\left(500 \mathrm{MHz}\right.$, acetone- $\left.d_{6}\right): 7.18$ $(2 \mathrm{H}, \mathrm{s}) ; 4.03(2 \mathrm{H}, \mathrm{d}, \mathrm{J}=6.5 \mathrm{~Hz}) ; 2.03-2.12(1 \mathrm{H}, \mathrm{m}) ; 1.03$ $(6 \mathrm{H}, \mathrm{d}, \mathrm{J}=6.5 \mathrm{~Hz}) ;{ }^{13} \mathrm{C}$ NMR $\left(125 \mathrm{MHz}\right.$, acetone- $\left.d_{6}\right)$ : $167.571 ; 146.911$ (2C); 139.490; 122.922; 110.627; 110.589; 71.787; 29.598; 20.299. HRMS El+ Calcd for $\mathrm{C}_{12} \mathrm{H}_{16} \mathrm{O}_{5}[M]^{+}:$226.0841, found: 226.0847 .

\section{Tert-butylgallate (7)}

Tert-butylgallate ( $182.7 \mathrm{mg}, 55 \%$ yield) was obtained from flash column chromatography on silica gel of the crude extract (gradient elution 20:1 to $1: 1 \mathrm{CHCl}_{3} / \mathrm{CH}_{3} \mathrm{OH}$ ) as a brown solid. $R_{f} 0.60$ (4:1 $\left.\mathrm{CHCl}_{3} / \mathrm{CH}_{3} \mathrm{OH}\right) ;{ }^{1} \mathrm{H}$ NMR $(500 \mathrm{MHz}$, acetone$\left.d_{6}\right): 7.07(2 \mathrm{H}, \mathrm{s}) ; 1.53(9 \mathrm{H}, \mathrm{s}) ;{ }^{13} \mathrm{C} \mathrm{NMR}(125 \mathrm{MHz}$, acetone- $\left.d_{6}\right)$ : 166.769; 146.577 (2C); 138.956; 124.333; 110.379 (2C); 81.096; 29.055 (3C). HRMS $\mathrm{El}^{+}$Calcd for $\mathrm{C}_{12} \mathrm{H}_{16} \mathrm{O}_{5}[\mathrm{M}]^{+}: 226.0841$, found: 226.0840 .

\section{Amylgallate (8)}

Amylgallate $(275.0 \mathrm{mg}, 78 \%$ yield) was obtained from flash column chromatography on silica gel of the crude extract (gradient elution 20:1 to $1: 1 \mathrm{CHCl}_{3} / \mathrm{CH}_{3} \mathrm{OH}$ ) as a dark brown solid. $R_{f} 0.62$ (4:1 $\left.\mathrm{CHCl}_{3} / \mathrm{CH}_{3} \mathrm{OH}\right) ;{ }^{1} \mathrm{H}$ NMR (500 MHz, acetone- $d_{6}$ ): $7.11(2 \mathrm{H}, \mathrm{s}) ; 4.19(2 \mathrm{H}, \mathrm{t}, \mathrm{J}=9.2 \mathrm{~Hz}) ; 1.73-1.65(2 \mathrm{H}, \mathrm{m})$; 1.43-1.29 (4H, m); $0.89(3 \mathrm{H}, \mathrm{t}, \mathrm{J}=8.0 \mathrm{~Hz}) \cdot{ }^{13} \mathrm{C}$ NMR $\left(125 \mathrm{MHz}\right.$, acetone- $\left.d_{6}\right): 166,751 ; 145.929(2 \mathrm{C})$; 138.566; 121.940; 109.664 (2C); 64.968; 29.123; 28.868; 22.932; 14.214. HRMS El+ Calcd for $\mathrm{C}_{12} \mathrm{H}_{16} \mathrm{O}_{5}[\mathrm{M}]^{+}: 240.0998$, found: 240.0994 .

\section{Isoamylgallate (9)}

Isoamylgallate $(230.5 \mathrm{mg}, 65 \%$ yield) was obtained from flash column chromatography on silica gel of the crude extract (gradient elution 20:1 to $1: 1 \mathrm{CHCl}_{3} / \mathrm{CH}_{3} \mathrm{OH}$ ) as a dark brown solid. $R_{f} 0.66$ (4:1 $\left.\mathrm{CHCl}_{3} / \mathrm{CH}_{3} \mathrm{OH}\right) ;{ }^{1} \mathrm{H}$ NMR (500 MHz, acetone- $\left.d_{6}\right)$ : $7.06(2 \mathrm{H}, \mathrm{s}) ; 4.19(2 \mathrm{H}, \mathrm{t}, \mathrm{J}=7.4 \mathrm{~Hz}) ; 1.77-1.66(1 \mathrm{H}, \mathrm{m})$; $1.55(2 \mathrm{H}, \mathrm{q}, \mathrm{J}=6.9 \mathrm{~Hz}) ; 0.89(6 \mathrm{H}, \mathrm{d}, \mathrm{J}=6.9 \mathrm{~Hz}) \cdot{ }^{13} \mathrm{C}$ NMR (125 MHz, acetone- $d_{6}$ ): 166,809; 146.063 (2C); $138.775 ; 121.702 ; 109.626$ (2C); 63.356; 38.108; 25.784; 22.694. HRMS El+ Calcd for $\mathrm{C}_{12} \mathrm{H}_{16} \mathrm{O}_{5}[\mathrm{M}]^{+}$: 240.0998, found: 240.0999 . 


\section{Hexylgallate (10)}

Hexylgallate (192.8 mg, 52\% yield) was obtained from flash column chromatography on silica gel of the crude extract (gradient elution 20:1 to $1: 1 \mathrm{CHCl}_{3} / \mathrm{CH}_{3} \mathrm{OH}$ ) as a dark brown solid. $R_{f} 0.70$ (4:1 $\left.\mathrm{CHCl}_{3} / \mathrm{CH}_{3} \mathrm{OH}\right) ;{ }^{1} \mathrm{H}$ NMR $\left(500 \mathrm{MHz}\right.$, acetone- $\left.d_{6}\right)$ : $7.11(2 \mathrm{H}, \mathrm{s}) ; 4.19(2 \mathrm{H}, \mathrm{t}, \mathrm{J}=8.6 \mathrm{~Hz}) ; 1.74-1.66(2 \mathrm{H}, \mathrm{m})$; $1.47-1.39(2 \mathrm{H}, \mathrm{m}) ; 1.36-1.30(4 \mathrm{H}, \mathrm{m}) ; 0.89(3 \mathrm{H}$, $\mathrm{t}, \mathrm{J}=8.0 \mathrm{~Hz}) \cdot{ }^{13} \mathrm{C}$ NMR $\left(125 \mathrm{MHz}\right.$, acetone- $\left.d_{6}\right)$ : $166.721 ; 146.023$ (2C); 138.484; 122.036 (2C), 109.645 (2C); 64.916; 42.041; 32.185; 26.412; 23.592; 14.243. HRMS El+ Calcd for $\mathrm{C}_{13} \mathrm{H}_{18} \mathrm{O}_{5}[\mathrm{M}]^{+}$: 254.1154, found: 254.1150 .

\section{Heptylgallate (11)}

Heptylgallate (197.2 mg, 50\% yield) was obtained from flash column chromatography on silica gel of the crude extract (gradient elution 20:1 to $1: 1 \mathrm{CHCl}_{3} / \mathrm{CH}_{3} \mathrm{OH}$ ) as a dark brown solid. $R_{f} 0.75$ (4:1 $\left.\mathrm{CHCl}_{3} / \mathrm{CH}_{3} \mathrm{OH}\right) ;{ }^{1} \mathrm{H}$ NMR $\left(500 \mathrm{MHz}\right.$, acetone- $\left.d_{6}\right)$ : $7.24(2 \mathrm{H}, \mathrm{s}) ; 4.18(2 \mathrm{H}, \mathrm{t}, \mathrm{J}=8.6 \mathrm{~Hz}) ; 2.08-2.03(2 \mathrm{H}$, $\mathrm{m}) ; 1.71-1.18(8 \mathrm{H}, \mathrm{m}) ; 0.88(3 \mathrm{H}, \mathrm{t}, \mathrm{J}=8.2 \mathrm{~Hz}) .{ }^{13} \mathrm{C}$ NMR $\left(125 \mathrm{MHz}\right.$, acetone- $\left.d_{6}\right): 166.885 ; 146.320$ (2C); 139.043; 121.587, 109.588 (2C); 64.844; $46.072 ; 32.442 ; 26.691 ; 23.190 ; 22.455 ; 14.281$. HRMS El+ Calcd for $\mathrm{C}_{14} \mathrm{H}_{20} \mathrm{O}_{5}[\mathrm{M}]^{+}: 268.1311$, found: 268.1324

\section{Octylgallate (12)}

Octylgallate $(210.3 \mathrm{mg}, 51 \%$ yield) was obtained from flash column chromatography on silica gel of the crude extract (gradient elution 20:1 to $1: 1 \mathrm{CHCl}_{3} / \mathrm{CH}_{3} \mathrm{OH}$ ) as a brown solid. $R_{f} 0.81(4: 1$ $\left.\mathrm{CHCl}_{3} / \mathrm{CH}_{3} \mathrm{OH}\right) ;{ }^{1} \mathrm{H}$ NMR $\left(500 \mathrm{MHz}\right.$, acetone- $\left.d_{6}\right)$ : $7.04(2 \mathrm{H}, \mathrm{s}) ; 4.24-4.07(2 \mathrm{H}, \mathrm{m}) ; 1.74-1.64(2 \mathrm{H}, \mathrm{m})$; 1.38-1.05 (10H, m); $0.86(3 \mathrm{H}, \mathrm{t}, \mathrm{J}=6.9 \mathrm{~Hz}) \cdot{ }^{13} \mathrm{C}$ NMR $\left(125 \mathrm{MHz}\right.$, acetone- $\left.d_{6}\right): 167.209 ; 146.978$ (2C); 141.274; 119.890, 109.312 (2C); 32.452 ; $26.748 ; 23.533 ; 23.209$ (2C); 22.560; 14.300. HRMS $\mathrm{El}^{+}$Calcd for $\mathrm{C}_{15} \mathrm{H}_{22} \mathrm{O}_{5}[\mathrm{M}]^{+}:$282.1467, found: 282.1458.

\section{4-monomethoxy-butylgallate (13)}

4-Monomethoxy-butylgallate in $97 \%$ yield was obtained from flash column chromatography on silica gel of the crude extract (gradient elution 20:1 to $1: 1 \mathrm{CHCl}_{3} / \mathrm{CH}_{3} \mathrm{OH}$ ) as a pale yellow oil. $R_{f}$ $0.53\left(4: 1 \mathrm{CHCl}_{3} / \mathrm{CH}_{3} \mathrm{OH}\right) ;{ }^{1} \mathrm{H}$ NMR $(500 \mathrm{MHz}$, acetone- $\left.d_{6}\right): 7.08(2 \mathrm{H}, \mathrm{s}) ; 4.21(2 \mathrm{H}, \mathrm{t}, \mathrm{J}=7.4 \mathrm{~Hz}) ; 3.83$ $(3 \mathrm{H}, \mathrm{s}) ; 1.72-1.65(2 \mathrm{H}, \mathrm{m}) ; 1.49-1.39(2 \mathrm{H}, \mathrm{m}) ; 0.94$
$(3 \mathrm{H}, \mathrm{t}, \mathrm{J}=8.6 \mathrm{~Hz}) .{ }^{13} \mathrm{C}$ NMR $\left(125 \mathrm{MHz}\right.$, acetone- $\left.d_{6}\right)$ : $162.955 ; 151.385 ; 140.359 ; 126.471 ; 109.540$; 64.882; 60.409; 36.191; 19.823; 13.947. HRMS El ${ }^{+}$ Calcd for $\mathrm{C}_{12} \mathrm{H}_{16} \mathrm{O}_{5}[\mathrm{M}]^{+}:$240.0998, found: 240.0996 .

\section{3,4-dimethoxy-butylgallate (14)}

3,4-dimethoxy-butylgallate in $89 \%$ yield was obtained from flash column chromatography on silica gel of the crude extract (gradient elution 20:1 to $1: 1 \mathrm{CHCl}_{3} / \mathrm{CH}_{3} \mathrm{OH}$ ) as a pale yellow oil. $R_{f}$ $0.56\left(4: 1 \mathrm{CHCl}_{3} / \mathrm{CH}_{3} \mathrm{OH}\right) ;{ }^{1} \mathrm{H}$ NMR $(500 \mathrm{MHz}$, acetone- $\left.d_{6}\right): 7.15(1 \mathrm{H}, \mathrm{d}, \mathrm{J}=2.3 \mathrm{~Hz}) ; 7.10(1 \mathrm{H}, \mathrm{d}, \mathrm{J}=$ $2.3 \mathrm{~Hz}) ; 4.21(2 \mathrm{H}, \mathrm{t}, \mathrm{J}=7.4 \mathrm{~Hz}) ; 3.83(3 \mathrm{H}, \mathrm{s}) ; 3.78$ $(3 \mathrm{H}, \mathrm{s}) ; 1.70-1.63(2 \mathrm{H}, \mathrm{m}) ; 1.46-1.37(2 \mathrm{H}, \mathrm{m}) ; 0.91$ $(3 \mathrm{H}, \mathrm{t}, \mathrm{J}=8.0 \mathrm{~Hz}) \cdot{ }^{13} \mathrm{C}$ NMR $\left(125 \mathrm{MHz}\right.$, acetone- $\left.d_{6}\right)$ : 166.427 ; 153.884; 151.156; 141.332; 126.557; $111.181 ; 105.563 ; 65.130 ; 60.704 ; 56.259 ; 31.460$; 19.842; 13.976. HRMS El Calcd for $\mathrm{C}_{13} \mathrm{H}_{18} \mathrm{O}_{5}[\mathrm{M}]^{+}$: 254.1154, found: 254.1163 .

\section{3,4,5-trimethoxy-butylgallate (15)}

$3,4,5$-Trimethoxy-butylgallate in $77 \%$ yield was obtained from flash column chromatography on silica gel of the crude extract (gradient elution 20:1 to $\left.1: 1 \mathrm{CHCl}_{3} / \mathrm{CH}_{3} \mathrm{OH}\right)$ as a pale yellow oil. $R_{f}$ 0.59 (4:1 $\left.\mathrm{CHCl}_{3} / \mathrm{CH}_{3} \mathrm{OH}\right) ;{ }^{1} \mathrm{H}$ NMR $(500 \mathrm{MHz}$, acetone- $\left.d_{6}\right): 7.17(2 \mathrm{H}, \mathrm{s}) ; 4.16(2 \mathrm{H}, \mathrm{t}, \mathrm{J}=6.9 \mathrm{~Hz}) ; 3.74$ $(6 \mathrm{H}, \mathrm{s}) ; 3.66(3 \mathrm{H}, \mathrm{s}) ; 1.63-1.56(2 \mathrm{H}, \mathrm{m}) ; 1.38-1.29$ $(2 \mathrm{H}, \mathrm{m}) ; 0.83(3 \mathrm{H}, \mathrm{t}, \mathrm{J}=7.4 \mathrm{~Hz}) \cdot{ }^{13} \mathrm{C} \mathrm{NMR}(125 \mathrm{MHz}$, acetone- $\left.d_{6}\right): 166.360 ; 154.084 ; 143.278 ; 107.537$; 107.509; 65.302; 60.599; 56.450; 31.488; 19.852; 13.995. HRMS El ${ }^{+}$Calcd for $\mathrm{C}_{14} \mathrm{H}_{20} \mathrm{O}_{5}[\mathrm{M}]^{+}: 268.1311$, found: 268.1313.

\section{In vitro and In vivo antimalarial activity evalution against Plasmodium falciparum}

Antimalaria activity evaluation was conducted using a microtiter plate that has 24 holes $(6 \times 4)$, with parasitemia counting methods provided by Trager and Jensen (1976). ${ }^{12}$ Into each well successively filled medium RPMI-1640 as base material for medium, gentamicin $25 \mu \mathrm{g} / \mathrm{mL}$, hypoxanthine $50 \mu \mathrm{g} / \mathrm{mL}, 25 \mathrm{mM}$ Hepes buffer, 25 $\mathrm{mM} \mathrm{NaHCO}, 10 \%$ human serum, and 5\% hematocrit and red blood cells containing Plasmodium falciparum parasites propagated Plasmodium falciparum 3D7 for 2 weeks (> $2 \%$ parasitemia). The $\mathrm{pH}$ of the medium is set at the physiological $\mathrm{pH}$, ie 7.4. Each of the synthesized compound was prepared by diluting $10^{-2}$ to $10^{-9} \mathrm{M}$ 
with a final volume of $1 \mathrm{~mL}$. Dilution of the substance using a complete medium containing $10 \%$ human serum. The culture plate is stored in a temperature incubator of $37{ }^{\circ} \mathrm{C}$ and the medium is replaced every 24 hours. Trial was done in three replicated (triplo). Negative control is Plasmodium falciparum culture in RPMI medium without addition of test compound. Parasite growth is monitored on the first day $(\mathrm{HO})$, ie the number of parasites before the test sample is given, and after $48 \mathrm{~h}$ of incubation $\left(\mathrm{H}_{2}\right)$. Observation based on thin blood smear from each well. After incubation period, each sample was prepared smear on the object glass, fixed with methanol, dried and stained with $10 \%$ Giemsa solution for 25 minutes. After rinsing with water and dried, the object glass is examined under a binocular microscope and parasitemia is calculated under 1000x magnification by using immersion oil. The percentage of parasitemia and growth percentage of Plasmodium falciparum and its resistance was obtained by counting the number of infected erythrocytes per field of view. Response data of test sample concentration on parasitic growth were analyzed by probit regression to determine $50 \%$ inhibitory concentration $\left(\mathrm{IC}_{50}\right) \cdot \mathrm{IC}_{50}$ is defined as the concentration of the test material which can inhibit the parasite growth of $50 \%$ relative to the control.

\section{RESULT AND DISCUSSION}

\section{Synthesis of alkyl esters gallate}

Synthetic pathway of the gallic acid derivatives of alkyl ester gallate 2-12 is presented in Scheme 1. Esterification of gallic acid with methanol, ethanol, n-propanol, n-butanol, isobutanol, $t$-butylalcohol, amylalcohol, isoamyl alcohol, n-hexanol, $\mathrm{n}$-heptanol and n-octanol using a combination of DIC and DMAP will give the product of alkyl esters gallate, successively is methylgallate (2), ethylgallate (3), propylgallate (4), butylgallate (5), isobutyl gallate (6), tert-butylgallate (7), amylgallate (8), Isoamyl gallate (9), hexylgallate (10), heptyl gallate (11) and octyl gallate (12) with a yield ranging from $50 \%$ to $78 \%$.

Synthetic pathway of gallic acid derivatives, methoxy alkylgallate 13-15, through the formation of intermediate $16-21$ is display in
Scheme 2. Alkyl ester 13, 14 and 15, can be prepared through three steps chemical reaction. In the first step, methylation of gallic acid (1) with $\mathrm{K}_{2} \mathrm{CO}_{3}$ and methyl iodide to give a mixed product of 4-monomethoxy methyl galate (16) in $61 \%$ yield, 3,4-dimethoxy methyl gallate (17) in $14 \%$ yield, and $3,4,5$-trimethoxy methylgalate (18) in $10 \%$ yield. In the second step, the hydrolysis of methyl ester 16 , 17 and 18 with aqueous $\mathrm{LiOH}$ monohydrate afforded 4-monomethoxy acid (19) in $90 \%$ yield, 3,4-dimethoxy gallic acid (20) in $80 \%$ yield and 3,4,5-trimethoxy gallic acid (21) in $85 \%$ yield, recpectively. Subsequently, in the third step, esterification of 4-monomethoxy galic acid (19), 3,4-dimethoxy gallic acid (20) and 3,4,5-trimethoxy galic acid (21) with n-butanol generated 4-monomethoxy butyl gallate (13) in $97 \%$ of yield, 3,4-dimethoxy butyl gallate (14) in $89 \%$ yield and 3,4,5-trimethoxy butyl gallate (15) in $77 \%$ yield, respectively.

\section{In vitro antimalarial activity of alkyl ester gallate and methoxy alkyl gallate}

In vitro antimalarial activity of galic acid derivative as a growth inhibitor of Plasmodium falciparum is expressed by $\mathrm{IC}_{50}$ value. The smaller the $I_{50}$ value the higher the antimalarial activity. In vitro antimalarial activity of the gallic acid, gallic acid derivatives 2-15, and artemisin are presented in Table 1. As shown in Table 1, all gallic acid derivatives, except propyl gallate $\left(\mathrm{IC}_{50}: 697.6 \mathrm{mM}\right)$ had better antimalarial activity than gallic acid $\left(\mathrm{IC}_{50}: 194,8 \mathrm{mM}\right)$, with IC50 values ranging from 0.03 $\mathrm{mM}$ to $184.5 \mathrm{mM}$. Compared to a linear chain of alkyl ester gallate with a branched chain of alkyl ester gallate, an alkyl ester gallate compound with a linear chain alkyl group showed a stronger antimalarial activity than an alkyl ester gallate with a branched chain alkyl group. It can be observed on the straight-chain four-carbon of butyl gallate $\left(\mathrm{IC}_{50}: 2,40 \mathrm{mM}\right)$ which has higher antimalarial activity than isobutyl gallate $\left(\mathrm{IC}_{50}: 184.5 \mathrm{mM}\right)$ and tert- butylgallate $\left(\mathrm{IC}_{50}: 104.7 \mathrm{mM}\right)$ Which also has four-carbon alkyl chains, but with branched structures.

Similar results were also demonstrated by a five-carbon straight chain of amyl gallate (IC50: $6.08 \mathrm{mM}$ ) which has higher antimalarial activity than 
the five-carbon chain branched chain of isoamyl gallate with $\mathrm{IC}_{50}$ value of $8.73 \mathrm{mM}$. Modification of the hydroxy group on the gallic acid with tmethoxy group will increase its antimalarial activity against Plasmodium falciparum. Among three methoxy alkyl gallates, the most active compound is 4,5-dimethoxy-butylgallate (14). 4-Monomethoxy butylgallate (13) and 3,4,5-trimethoxy butylgallate (15) have a lower antimalarial activity compared to 3,4-dimethoxy butylgallate (14). This revealed that the replacement of the two hydroxy groups in the butyl gallate into dimethoxy butyl gallate resulted in increasing of antimalarial activity. Among fourteen synthesized alkyl ester derivatives of gallic acid, methylgallate (2) and hexylgallate (10) showed better antimalarial activity than gallic acid and artemisin $\left(\mathrm{IC}_{50}: 0.50 \mathrm{mM}\right)$ as positive control, with IC50 values of $0.03 \mathrm{mM}$ and $0.11 \mathrm{mM}$, respectively. These results suggest that methylgallate and hexyl gallate could be further developed as an antimalarial agent that potentially inhibits the growth of Plasmodium falciparum.
Table 1: Antimalarial activity $\left(\right.$ IC $_{50}$ ) of gallic acid, alkyl esters gallate and artemisin

\begin{tabular}{llc}
\hline No & Compound & $\begin{array}{c}\text { Antimalarial } \\
\text { activity } \\
\left(\mathrm{IC}_{50}, \mathrm{mM}\right)\end{array}$ \\
\hline 1 & Gallic acid (1) & 194.85 \\
2 & Methylgallate (2) & 0.03 \\
3 & Ethylgallate (3) & 2.95 \\
4 & Propylgallate (4) & 697.6 \\
5 & Butylgallate (5) & 2.40 \\
6 & Isobutylgallate (6) & 184.5 \\
7 & Tert-butyl gallate (7) & 104.7 \\
8 & Amylgallate (8) & 6.08 \\
9 & Isoamylgallate (9) & 8.73 \\
10 & Hexylgallate (10) & 0.11 \\
11 & Heptylgallate (11) & 24.87 \\
12 & Octylgallate (12) & 8.47 \\
13 & 4-Monomethoxy-butylgallate (13) & 22.70 \\
14 & 3,4-Dimethoxy-butylgallate (14) & 1.63 \\
15 & 3,4,5-Trimethoxy-butylgallate (15) & 76.4 \\
16 & Artemisin (positive control) & 0.50 \\
\hline
\end{tabular}<smiles>O=C(O)c1cc(O)c(O)c(O)c1</smiles>

Gallic acid (1)<smiles>O=C(O)c1cc(O)c(O)c(O)c1</smiles>

(2), $\mathrm{R}=-\mathrm{CH}$

Ethylgallate (3), $\mathrm{R}=-\mathrm{C}_{2} \mathrm{H}_{5}$

Propylgallate (4), $\mathrm{R}=-\mathrm{C}_{3} \mathrm{H}_{7}$

Butylgallate (5), $\mathrm{R}=-\mathrm{C}_{4} \mathrm{H}_{9}$

Isobutylgallate (6), $\mathrm{R}=-\mathrm{CH}_{2} \mathrm{CH}\left(\mathrm{CH}_{3}\right)_{2}$

t-butylgallate (7), $\mathrm{R}=-\mathrm{C}\left(\mathrm{CH}_{3}\right)_{3}$

Amylgallate $\quad(8), \mathrm{R}=-\mathrm{C}_{5} \mathrm{H}_{11}$

Isoamylgallate (9), $\mathrm{R}=-\left(\mathrm{CH}_{2}\right)_{2} \mathrm{C}\left(\mathrm{CH}_{3}\right)_{2}$

Hexylgallate (10), $\mathrm{R}=-\mathrm{C}_{6} \mathrm{H}_{13}$

Heptylgallate (11), R= $-\mathrm{C}_{7} \mathrm{H}_{15}$

Octylgallate (12), $\mathrm{R}=-\mathrm{C}_{8} \mathrm{H}_{17}$

Scheme 1. Synthetic pathway of alkyl esters derivative of gallic acid 2-15<smiles>CCCCCOC(=O)c1cc(O)c(O)c(O)c1</smiles>

Scheme 2. Synthetic pathway of alkyl ester 13,14 and 15 


\section{CONCLUSION}

Alkyl ester derivative of gallic acid, compound 2-15 have been successfully in good yield. Among fourteen derivatives, methylgallate and hexyl gallate exhibited the strongest antimalarial activity against Plasmodium falciparum. Thus, methyl gallate and hexylgallate should be considered as a promising candidate for the new antimalarial agent.

\section{ACKNOWLEDGEMENT}

We thank to Directorate of Research and community service (DRPM) University of Indonesia, and Directorate for higher education, Ministry of Research and Technology Republic of Indonesia for the PUPT (Penelitian Unggulan Perguruan Tinggi) research grant, and to the Graduate School of Materials Science, Nara Institute of Science and Technology (NAIST), Japan for International Research Collaboration Program (NAIST Global Initiative Program).

\section{REFERENCES}

1. Olumes $P$, Guidelines for the treatment of malaria. $2^{\text {nd }}$ edition. Switzerland:WHO., 2010.

2. Jacquerioz FA, Croft AM. Drugs for preventing malaria in travellers (Review). The Cochrane Library., 2010.

3. Margaret C, World malaria report. Switzerland: WHO., 2011.

4. Epidemiology of Malaria in Indonesia. Buletin Jendela Data dan Informasi, Vol. 1, Triwulan 1. Ministry of Health Republic of Indonesia 2011. Available from: http://www.file:///C:/ users/user/ download/buletin-malaria.pdf

5. Indonesia National Malaysia Control Program Strategic Plan 2015-2019. Ministry of Health Republic Indonesia 2014. Available from http://wwww.static1.1. sqspcdn.com/ststic/f/471029/26502872/ 1441109745877/summary-of-national-malariacontrol-program-strategis-plan 2015edas.pdf

6. Irianto K, Parasitologi berbagai penyakit yang mempengaruhi kesehatan manusia. Penerbit Yrama Widya,Bandung., 2009.

7. Muttabingwa TK.; Anthony D.; Heller A.; Hallet R.; Ahmed J.; Drakeley C.; Greenwood BM.; Whitney CJ Amodiaquine alone amodiaquine+sulfadoxine-pyrimethamine, amodiaquine+artesunate, and artemetherlumefantrine for outpatient treatment of malaria in Tanzania children: a four-arm randomized effectiveness trial. Lancet., 2005, 365, 1474-1480.

8. Sannela AR.; Messori L.; Casini A.; Vincieri FF.; Bilia AR.; Majori G.; Antimalarial properties of green tea. Biol Pharma Bull, 2010, 31, 903-907.

9. El Babili F.; Bouajila J.; Souchard JP.; Bertrand C.; Bellvert F.; Fouraste I.; Moulis C.; Valentin A.; Oregano:Chemical analysis and evaluation of its antimalarial, antioxidant, and cytotoxic activities. J.Food Sci. 2011, 76(3), 512-518.

10. Murphy A.; Lang-Unnasch N.; Aternative Oxidaselnhibitors Potentiate the Activity of Atovaquone against Plasmodium falciparum Antimicrobial Agents and Chemotherapy, 1999, 43(3), 651-654.

11. Arsianti A.; Astuty H.; Fadilah.; Bahtiar A.; Tanimoto H.; Kakiuchi K.; Design and Screening of Gallic Acid Derivatives as Inhibitors of Malarial Dihydrofolate Reductase by In Silico Docking. Asian J Pharm Clin Res, 2017, 10(2), 330-334.

12. Trager W.; Jensen JB.; Human Malaria parasites in continuous culture. Science, 1976, 193(4254), 673-675. 